\title{
Cold Tolerance in Rice Plants: Phenotyping Procedures for Physiological Breeding
}

\author{
Diogo S. Moura ${ }^{1}$, Giovani G. Brito ${ }^{2}$, Ítalo L. Moraes ${ }^{1}$, Paulo R. R. Fagundes ${ }^{2}$, Adriano P. Castro $^{3} \&$ Sidnei Deuner ${ }^{1}$ \\ ${ }^{1}$ Federal University of Pelotas, Campus Capão do Leão, RS, Brazil \\ ${ }^{2}$ EMBRAPA Temperate Climate, Brazilian Agricultural Research Corporation, Pelotas, RS, Brazil \\ ${ }^{3}$ EMBRAPA Rice and Beans, Brazilian Agricultural Research Corporation, Goiânia, GO, Brazil \\ Correspondence: Giovani G. Brito, EMBRAPA Temperate Climate, Brazilian Agricultural Research Corporation, \\ Pelotas, RS, Brazil. E-mail: giovani.brito@embrapa.br
}

Received: November 5, 2017

Accepted: December 2, 2017 Online Published: December 15, 2017

doi:10.5539/jas.v10n1p313

URL: https://doi.org/10.5539/jas.v10n1p313

\begin{abstract}
The study was conducted using physiological approach to identify rice accessions with superior performance when subjected to infra-optimum temperatures during initial development phase $\left(\mathrm{V}_{2}-\mathrm{V}_{4}\right)$. Forty-two rice genotypes composed by background essentially indica, japonica and indica/japonica cross with a broad genetic and ecological diversity were used. Plants were grown under initial optimum temperatures gradient (OTG $22 / 32{ }^{\circ} \mathrm{C}$ night/day) until V2 stage; subsequently were subjected to infra-optimum temperature gradient (ITG $13 / 17^{\circ} \mathrm{C}$ night/day) during three days; after all genotypes returned to OTG conditions for seven days to recovery. Principal components analysis (PCA) highlighted that the three principal components account for $75.16 \%$ of total variation at the end of evaluated period. There were similar contributions of effective quantum yield (Y(II) stress) and electron transport rate variables after recovery period (ETR - recovery) for PC1. Interestedly, genotypes highly responsive under initial OTG which showed fast initial biomass accumulation were also highly sensitive to stress when subjected to ITG, with accentuated decreases in their physiological performance. Sel. TB 1211-3 line, CTB 1419, СТВ 1444, СТВ 1455 and AB 13720 progenies showed greater performance for physiological analyzed variables, being potentially useful for breeding efforts aiming improve cold tolerance in rice at initial phase.
\end{abstract}

Keywords: Oryza, cold tolerance, chlorophyll fluorescence, rice physiology, chilling, extreme climate events

\section{Introduction}

The increasingly occurrence of extreme climate events and those forecast to occur yet in the century wave us that our current decisions will determine the size of the climatic impacts on earth life in the next years. Although is unclear the impacts of these changes on agricultural sustainability, in the current year the $\mathrm{CO}_{2}$ concentration reached unprecedented registered levels on earth surface (about $403 \mathrm{ppm}$ ) (Olivier et al., 2017). In this way, add to challenges associated to feed more than nine billions people in the next decades (Jacquemin et al., 2013; Fan et al., 2014), an additional question is related to how to supply the food crescent demand for world growth population in face of increasingly uncertainties about climate stability; which could lead to change of rain regime, besides of increases in frequency of heat and cold waves as predicted to be increasingly common in next decades. In this sense, abiotic and biotic stresses are the major constraints for agricultural productivity on the global scale and projected climate changes could increase their negative effects in the future (Brito et al., 2010, 2011; Diola et al., 2011; Diola et al., 2013; Weber et al., 2014; Brito et al., 2016; Guimarães et al., 2017; Lisei-de-Sa et al., 2017; Moura et al., 2017a; Moura et al., 2017b) and its increasingly frequency of occurrence will probably influence the plant species distributions, productivity, carbon balance and negatively impacting on physiological resilience capacity of plants in a specific environment. Thus, is imperative to consider that the major challenge is how to overcome this barriers increasing rice production using less land, water, chemicals, and labor; additionally, considering the need to conserve the environmental and natural resources of degradation. In this way, efforts and new strategies are necessary to be included in the breeding program aiming to accelerate the construction of new plant types for new economics and climate scenarios. 
Rice (Oryza sativa L.) is one of the most relevant staple food for more than half of the world's population (Fan et al., 2016). Rice production must be increased by $70 \%$ until 2050 to supply the growing demand for food, take into account the growth population and economic development (Godfray et al., 2010). For rice early development, which involve an adequate germination and seedling establishment, this specie require temperatures situated between 20 and $35^{\circ} \mathrm{C}$ (Yoshida, 1981). Stress by infra-optimum temperatures occurs when the temperature falls below $17^{\circ} \mathrm{C}$ resulting in poor germination, slowing seedling biomass accumulation, besides poor stand establishment and, consequently decreases of the yield components and productivity (Shakiba et al., 2017; Zhao et al., 2017). In this sense, according to the historic weather record, from years 1971-2000 (http://agromet.cpact.embrapa.br/estacao/mensal.html), in Brazil southern, specifically in Rio Grande do Sul state were cropped about $70 \%$ of Brazilian rice (1.1 million hectares approximately) (Conab, 2017), the coldest period is situated between mid-May to the mid-October. Our historic weather data are evidencing an increase in the temperatures oscillations during rice crop development. Heat and cold waves are becoming increasingly in last decades; especially during September and mid-October when rice crops are still at an early stage of plant development.

Despite of the high sensitivity of rice to infra-optimum temperatures, the variability in the germplasm bank should be exploited, where range of infra-optimum temperature tolerance exist among accessions of indica and japonica subspecies. Even though considering that indica ssp accessions are more sensitive to this specific stress, the increased use of japonica ssp in breeding programs around world has allowed the insertion of valorous alleles, which needs to be identified, dissected and used to accelerate the breeding processes aiming to develop cultivars with improved tolerance to infra-optimum temperatures.

In this way, whereas great progresses have been made in the cost-efficiency and high-throughput analyses of genetic information as results of "omics" advances, and by increasingly availability of phenotyping platforms able to be used in large-scale, yet exist gaps and bottlenecks which difficult the association of external morphometrics parameters to physiological phenotyping and/or the mechanisms related to plant stress responses. As discussed by different authors, efforts should be done by multidisciplinary expertise allowing that complex traits could be broken down into individual components; beyond to be dissected, validated and checked across different scales to become useful as physiological proxy underlying processes used for plants in response to a specific stimulus.

Although different studies have demonstrated the effects of infra-optimum temperatures on rice physiological performance, most of these studies have been carried out under unique and static temperature for night and also for day period; what reduce its consistency when compared with realistic and dynamic environment changes in the field, where plants will be subjected in the future. By other side, studies conducted under field conditions yet involve laborious procedures, besides leads to increases in the trial errors resultant of variability in the soil chemicals composition, physical properties and management practices. Thus, aiming to increase consistency of generated data in this study, a physiological phenotyping platform was used allowing to simulate temperatures gradient during night and day periods, beyond control of humidity, carbon dioxide quantity, ethylene levels, light intensity and its spectral quality. Other devices such as fluorometer imaging, infra-red camera, root scanners and infra-red gas analyzer integrate this phenotyping platform.

In this sense, this study aimed to apply non-invasive physiological procedures, via chlorophyll fluorescence parameters to phenotype multiple genotypes in response to infra-optimum temperature; in addition, adopted multivariate analysis to discriminate those with great potential to be included in new efforts in the breeding program aiming to obtain lines/cultivars with improved resilience in face to infra-optimum temperatures occurrence.

\section{Material and Methods}

\subsection{Plant Materials}

The study was based on our previews trials from Embrapa's Rice Breeding Program and involved forty-two rice genotypes composed by background essentially indica, japonica and indicaljaponica cross with a broad genetic and ecological diversity (Table 1). For this purpose was included two cold-tolerant genotypes named as Tomoe Mochi and Diamante based in our previous trials, which compounded our genetic materials in the study. 
Table 1. Genotypes of the Embrapa's rice breeding program from different origins and genetic background used for this study

\begin{tabular}{|c|c|c|}
\hline Genotypes & Crossing combinations & Sub-species \\
\hline 86914-IR 891-7-2-1 & Unavailable source & Japonica \\
\hline HSC 16 & Unavailable source & Indica \\
\hline LTB 06012 & Unavailable source & Indica \\
\hline LTB 050055 & CNA 8621/CNAi 9025 & Indica \\
\hline LTB 050151 & BRS-7 Taim/CL Sel. 720 & Indica \\
\hline LTB 07041 & CL 113-4-1-1/CL 591 & Indica \\
\hline LTB 07048 & IR 3825-B-B-23/CL 591 & Indica \\
\hline AB 10572 & BRA 01016/BRA 02676 & Indica \\
\hline AB 10501 & CNAx12967-B-2-B-8-B & Indica \\
\hline AB 13002 & BRA 01330/CNAx 11208-B-21-B & Indica/Japonica \\
\hline AB 13008 & BRS Fronteira/BR IRGA 409 & Indica \\
\hline AB 13012 & BRS Querência/IRGA 417 & Indica/Japonica \\
\hline AB 12597 & BRA 01028/IRGA 419 & Indica \\
\hline AB 11502 & IRGA 417/IRGA 419 & Indica \\
\hline AB 13715 & CNA 5/3/1-29-B-B-4-B/BRA 040081 & Indica/Japonica \\
\hline AB 13720 & BRA 01330/CNAx 11208-B-21-B & Indica/Japonica \\
\hline AB 14001 & BRS Fronteira/BR IRGA 409 & Indica \\
\hline AB 13006 & BRS Fronteira/BR IRGA 409 & Indica \\
\hline AB 13689 & SCS 112/IRGA 417 & Indica/Japonica \\
\hline AB 13003 & Sel. Em SC 766 & Indica/Japonica \\
\hline СТВ 1414 & Sel. TB 1211-1/BRS-6 Chuí & Indica/Japonica \\
\hline СТВ 1417 & Sel. TB 1211-2/BRS Pampa & Indica/Japonica \\
\hline СТВ 1418 & Sel. TB 1211-2/BRS-6 Chuí & Indica/Japonica \\
\hline СТВ 1419 & Sel. TB 1211-2/IRGA 424 & Indica/Japonica \\
\hline СТВ 1421 & Sel. TB 1211-3/IRGA 424 & Indica/Japonica \\
\hline СТВ 1424 & Sel. TB 1211-5/IRGA 424 & Indica/Japonica \\
\hline СТВ 1425 & AB 10004/BRS Pampa & Indica \\
\hline СТВ 1442 & Sel. TB 1211-1/AB09007 & Indica/Japonica \\
\hline СТВ 1444 & Sel. TB 1211-1/BRA051108 & Indica/Japonica \\
\hline СТВ 1445 & Sel. TB 1211-1/BRA 051077 & Indica/Japonica \\
\hline СТВ 1447 & Sel. TB 1211-2/INTA Puitá CL & Indica/Japonica \\
\hline СТВ 1449 & Sel. TB 1211-2/BRA051077 & Indica/Japonica \\
\hline СТВ 1450 & Sel. TB 1211-3/INTA Puitá CL & Indica/Japonica \\
\hline СТВ 1454 & Sel. TB 1211-5/BRA 051108 & Indica/Japonica \\
\hline CTB 1455 & Sel. TB 1211-5/BRA051077 & Indica/Japonica \\
\hline СТВ 1457 & AB 10007/BRS 6 Chuí & Indica/Japonica \\
\hline Sel. TB 1211-1 & CL 113-4-1-1/CL 591 & Indica/Japonica \\
\hline Sel. TB 1211-2 & CL 113-4-1-1/CL 591 & Indica/Japonica \\
\hline Sel. TB 1211-3 & CL 113-4-1-1/CL 591 & Indica/Japonica \\
\hline Sel. TB 1211-5 & CL 113-4-1-1/CL 591 & Indica/Japonica \\
\hline Diamante & Tolerant check & Japonica \\
\hline Tomoe Mochi & Tolerant check & Japonica \\
\hline
\end{tabular}

\subsection{Growth Conditions and Temperature Treatments}

Rice plants were grown in plastic trays filled with non-sterile substrate composed of a mixture of plant substrate (black peat, vegetable compost, $\mathrm{pH} 5.8 \pm 0.2$, electric conductivity $(\mathrm{mS} / \mathrm{cm}) 0.7 \pm 0.2$, water retention capacity (\%) $80.0, \mathrm{~N}(\%) 0.04, \mathrm{P}_{2} \mathrm{O}_{5}(\%) 0.04$ and $\mathrm{K}_{2} \mathrm{O}(\%) 0.05$. Immediately after sowing, the materials were maintained at the Embrapa's phenotyping platform (PhenoSTRESS) during all trial period (Figure 1). 

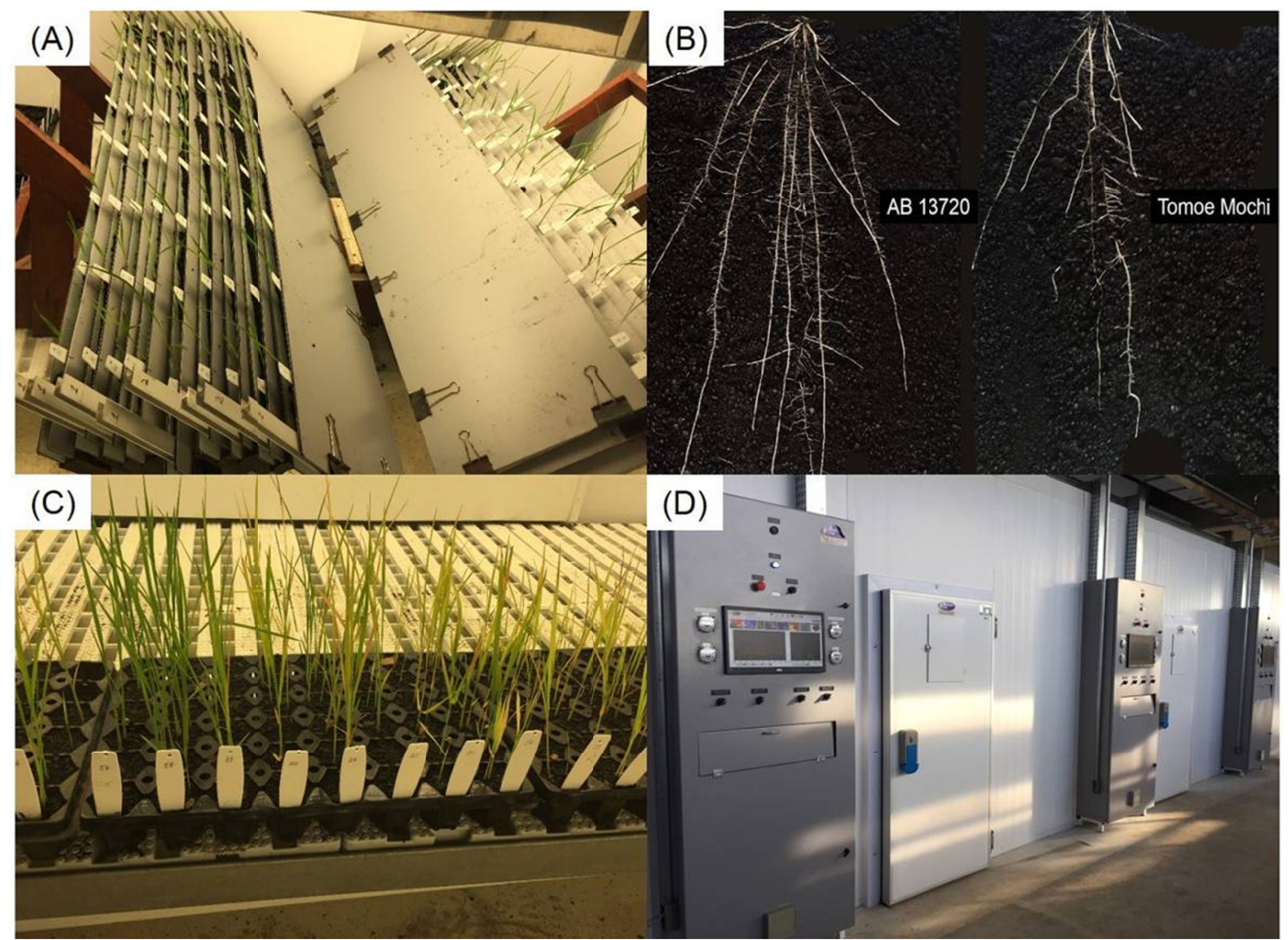

Figure 1. Facilities (Embrapa's PhenoSTRESS phenotyping platform) used for simulate infra-optimum temperatures regime imposed during trial period. Including rizhotrons used for root morphometric measurements (A); root view of the opened rizhotrons (B) and plant shoot aspects (C) at the end of recovery period; growth chambers used for study (D)

The growth chamber was programmed to simulate more realistic environment temperature changes based in historical climatic data from the most representative Brazilian rice producer region. Plants were grown under initial optimum temperatures gradient (OTG - $22 / 32{ }^{\circ} \mathrm{C}$ night/day), since sowing until V2 stage (Counce et al., 2000); subsequently plants were subjected to infra-optimum temperature gradient (ITG $-13 / 17^{\circ} \mathrm{C}$ night/day) for three days; after that, all genotypes were returned to OTG conditions during seven days for recovery (Figure 2); during trial period the growth chamber humidity was constant $(50 \pm 10 \%)$, being the dark period $(10 \mathrm{~h})$, for the light period (14 h) at $500 \mu \mathrm{mol} \mathrm{m} \mathrm{s}^{-2}$, approximately. 


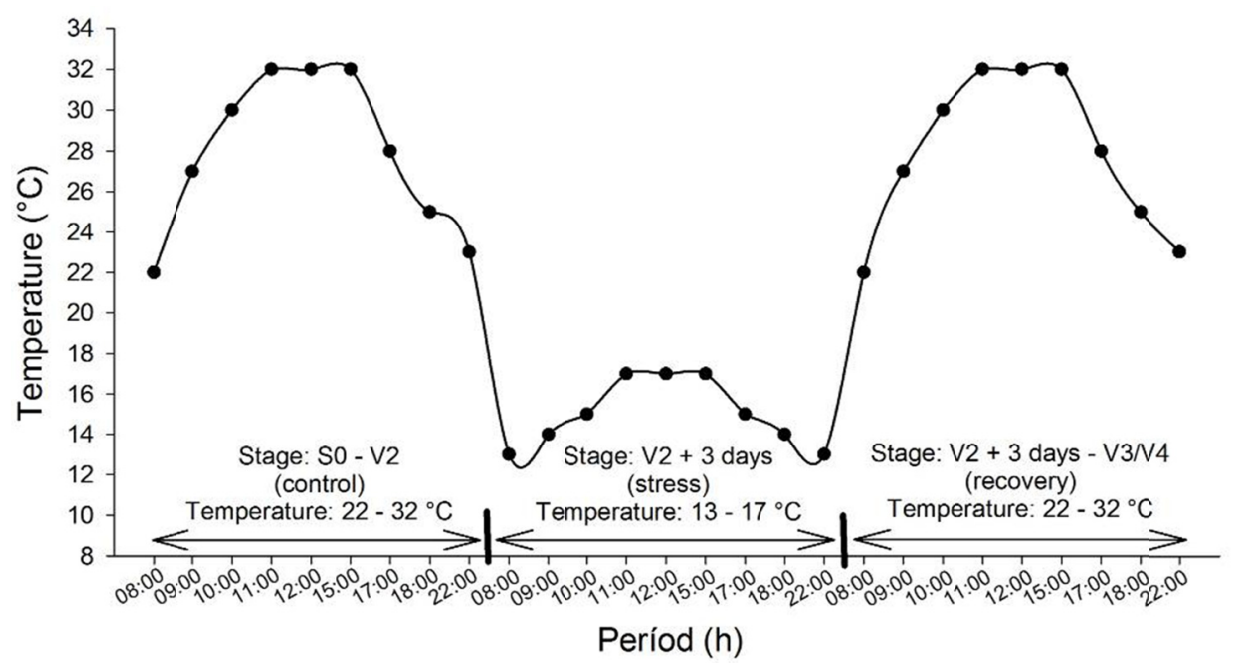

Figure 2. Dynamic variation of climatic conditions, showing the different temperatures regimes imposing during various stages of rice plants development; beyond evidencing the stages named as $\mathrm{V} 2+3$ days which refer to period where plants were exposed to infra-optimum temperatures

Six biological replicates of each treatment were carried out considering the required time for physiological analyzes. These analyzes were at fourteenth day (immediately before stress imposing) when plants reached V2 stage, at the third day after stress imposing (at the end of stress period) and at the seventh day post recovery period.

\subsection{Chlorophyll Fluorescence Measurements}

Chlorophyll fluorescence analyzes were done using a PAM-2500 fluorometer (Walz Heinz GmbH, Effeltrich, Germany). Before measurements, all genotypes were light-adapted at least one hour within the grow chamber programmed to maintain light at $500 \mu \mathrm{mol} \mathrm{m} \mathrm{s}^{-1}$, humidity at $50 \pm 10 \%$ and $\mathrm{CO}_{2}$ concentration at $400 \pm 30 \mu \mathrm{mol}$. During analyses, the internal growth chamber temperatures was programmed to maintain $22 \pm 1{ }^{\circ} \mathrm{C}, 13 \pm 1{ }^{\circ} \mathrm{C}$ and $22 \pm 1{ }^{\circ} \mathrm{C}$ for first (immediately before stress imposing), at second (at the end of stress period) and at third (after stress recovery), respectively. Thus, under these conditions the minimum fluorescence (Fo') of photosystem II (PSII) centers at partially reduced to the state was determined. The Fo' correspond to the momentary fluorescence yield (Ft) of an illuminated sample shortly before application of a saturation pulse. Whereas the maximum fluorescence (Fm') at partially closed or in a reduced state of PSII centers was also evaluated after a application of a $0.8 \mathrm{~s}$ pulse of saturating light $\left(7000 \mu \mathrm{mol} \mathrm{m} \mathrm{m}^{-2} \mathrm{~s}^{-1}\right)$. The effective photochemical quantum yield of PSII (Y(II)) was defined as (Fm' - F)/Fm'. During measurements the actinic light (red light) was turned on to quantify the steady-state of chlorophyll fluorescence (Fs). Summarizing, Fm' parameter was quantified in plants subjected to light-adapted state via application of a saturating pulse, whereas $\mathrm{F}_{0}$ ' was evaluated by switching off the actinic light for two seconds after the saturating pulse and turned on the far-red light. The electron transport rate (ETR) was calculate as PAR.ETR-factor.PPS2/PPPS.Y(II) (Baker, 2008).

\subsection{Non-Destructive Leaf Chlorophyll Determination}

Leaves chlorophyll content (Chl) was non-destructively monitored using a Dualex 4 Scientific (Dx 4) (FORCE-A, Orsay, France). Three random spots on the adaxial side of six youngest leaves per plot were monitored $(n=18)$, in a relative position of $2 / 3$ of the distance relative to leaf base; this position can better represent the leaf chlorophyll content in a rice flag leaf, as demonstrated by Yuan et al. (2016).

\subsection{Non-Destructive Root Morphometrics Phenotyping}

Additionally, as an alternative for non-destructive root trait measurements of 42 genotypes in study, rhizotrons were constructed to monitor, visualize and preserve the root architecture and morphology of rice plants in order to compare the root trait attributes subjected to different temperatures regimes. Each rhizotron consisted of two transparent aluminized sheets of $50.0 \mathrm{~cm}$ high, $1.2 \mathrm{~m}$ wide and $4.0 \mathrm{~mm}$ thick. The two sheets were separated on three sides (two long sides and one of the short sides) by $0.9 \mathrm{~cm}$ aluminum spacers and were held with fold back paper clips. The rhizotrons were filled with $1220 \mathrm{~g}$ of black substrate as described in detail above. Rhizotrons 
were placed with an inclination of $42^{\circ}$ relatively to vertical position and covered with black plastic sheet to exclude light from the soil and roots, leaving small slits for seedlings to emerge. Before sowing, the rhizotrons were watered to field capacity and the plants were maintained at $80 \%$ of its field capacity during all trial period. Similarly as described before (at V2 $2_{\text {control }}, \mathrm{V} 2+3$ days $_{\text {stress }}$ and $\mathrm{V} 3 / \mathrm{V} 4_{\text {recovery }}$ ) root imaging acquisition was done using a camera (Sony Cyber Shot DSC-HX1, Optical Zoom 20X) and the photographed images were analyzed with WinRHIZO Pro image analysis system (Regent Instruments, Inc., Quebec City, QC) to estimate total root length (sum of the lengths of all roots in the root system), total root surface area, total root volume, average root diameter, length and surface area and RLD of roots in 0-50 cm soil depth.

\subsection{Biomass Determination}

After recovery period, in the rizotrons, the total shoot and root dry weight were quantified harvesting each plant separately; these organs were immediately subjected to oven drying for $72 \mathrm{~h}$ at $70{ }^{\circ} \mathrm{C}$ for biomass determinations.

\subsection{Statistical Procedures}

The data was submitted to analyses of variance being carried out using SigmaPlot version 13 (Systat Software Inc., San Jose, CA, USA). In addition, principal component analysis (PCA) was performed to identify those potentially more tolerant to infra-optimum temperatures among genotypes and excluding those redundant evaluated parameters. These PCA step-by-step procedures allowed us to exclude sixteen redundant morphometrics and physiological variables which showed equal contributions. Subsequently, data from those contrasting genotype for each evaluated parameters were again subjected to ANOVA procedures aiming to test existence of the interaction between the different points evaluations and genotypes; when statistically significance was detected, unfold statistical procedures were done to quantify the effects of each genetic background within each point physiological analysis (before stress imposing, at the end of stress period and at recovery) (SigmaPlot 13.0 - Systat Software San Jose). Subsequently, the Least Significant Difference (LSD) among the means was statistically analyzed using Student-Newman-Keuls test $(\mathrm{p}<0.05)$.

\section{Results}

In this way, is needed to remember that rice plant has an optimal temperature threshold situated between 20 and $35^{\circ} \mathrm{C}$ (Yoshida, 1981). Thus, soil and air temperatures bellow of this threshold during initial phases can lead to decreases in germination rate, slow biomass accumulation, increases in plant mortality and, consequently reducing plant stand per area, negatively affecting its yield components.

In our study, a multivariate analysis via PCA was performed on various physiological variables under investigation and three principal components (PCs) were considered. PC1, PC2 and PC3 contributed to variations of 39.08, 22.70 and $13.48 \%$, respectively (Figures 3A and 3B). PCs indicated that three important components accounted for 75.26 percent of the total variation among traits in rice genotypes when subjected to stress conditions. Although the first component assigned 39.08 percent of total variation between traits with significant contribution of total root and shoot dry mass, is very important emphasize that the fast biomass accumulation performance shown by some genotypes occurred in the first days after plants germination, before stress imposing. Additionally, was evident that these parameters were nearly orthogonal with physiological measured variables. Therefore, highlighting that genotypes showing better physiological performance nearly always were those with lower shoot and root dry mass at the end of trial period. PCA procedures allowed us to uncover and consequently discriminate the Sel. TB 1211-3, CTB 1419, CTB 1444, CTB 1455 and AB 13720 genotypes which showed greater performance for the physiological analyzed variables (Figures 3C and 3D). 

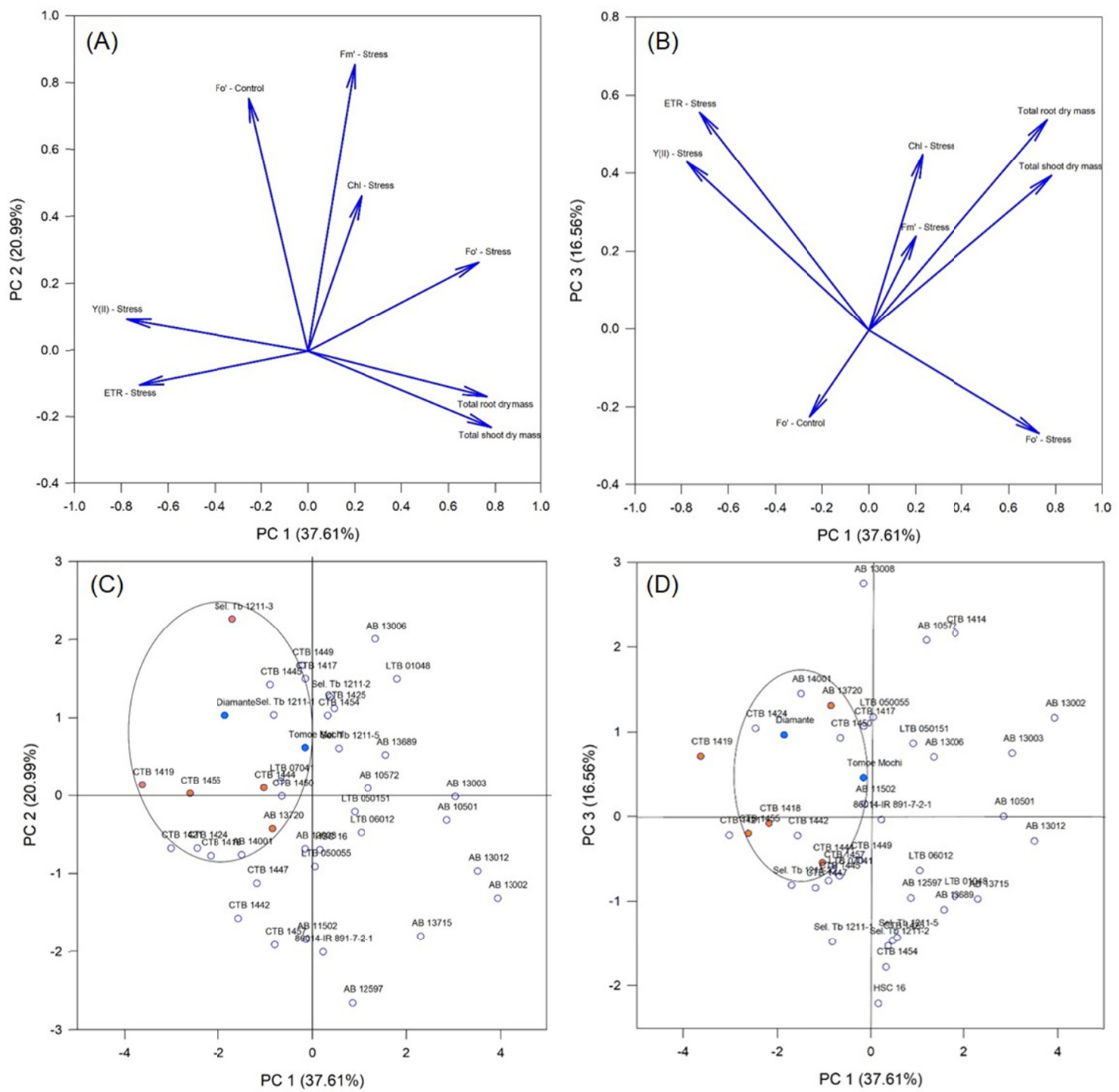

Figure 3. Principal component analysis (PCA) for morphometric and physiological responses in 42 rice genotypes. PC1-PC2 and PC1-PC3 variables loading plots during all trial period

Subsequently, these selected genotypes were subject to additional statistical analyses aiming to check its physiological stability across time evaluations, including its recovery capacity at the end of the stress period. Among selected genotypes, CTB 1419 showed higher effective quantum yield performance Y(II) whether compared to Sel. TB 1211-3 at the end of stress period (Figure 4A). However, after recovery period a similar performance was evidenced between these two genotypes. Data indicate still that Sel. TB 1211-3 showed greater stability across time point analyses considering its ETR values when compared to CTB 1419 (Figure 4B). For Fm' both genotypes showed a tendency to return to initial condition (non-stress) at recovery, even dough the Sel. TB 1211-3 also was better recovery performance at the end of evaluation period (Figure 4C). Although evidenced a lower ETR values when compared to CTB 1419, the Sel. TB 1211-3 line maintained unaltered its performance at the end of stress period whereas CTB 1419 showed an abrupt reduction $(31.20 \%)$ for this variable. After the stress period, again was highlighted higher stability of the Sel. TB 1211-3 for chlorophyll content $(+1.2 \%)$ whether compared to CTB 1419 (-49\%) during stress period (Figure 4D). 

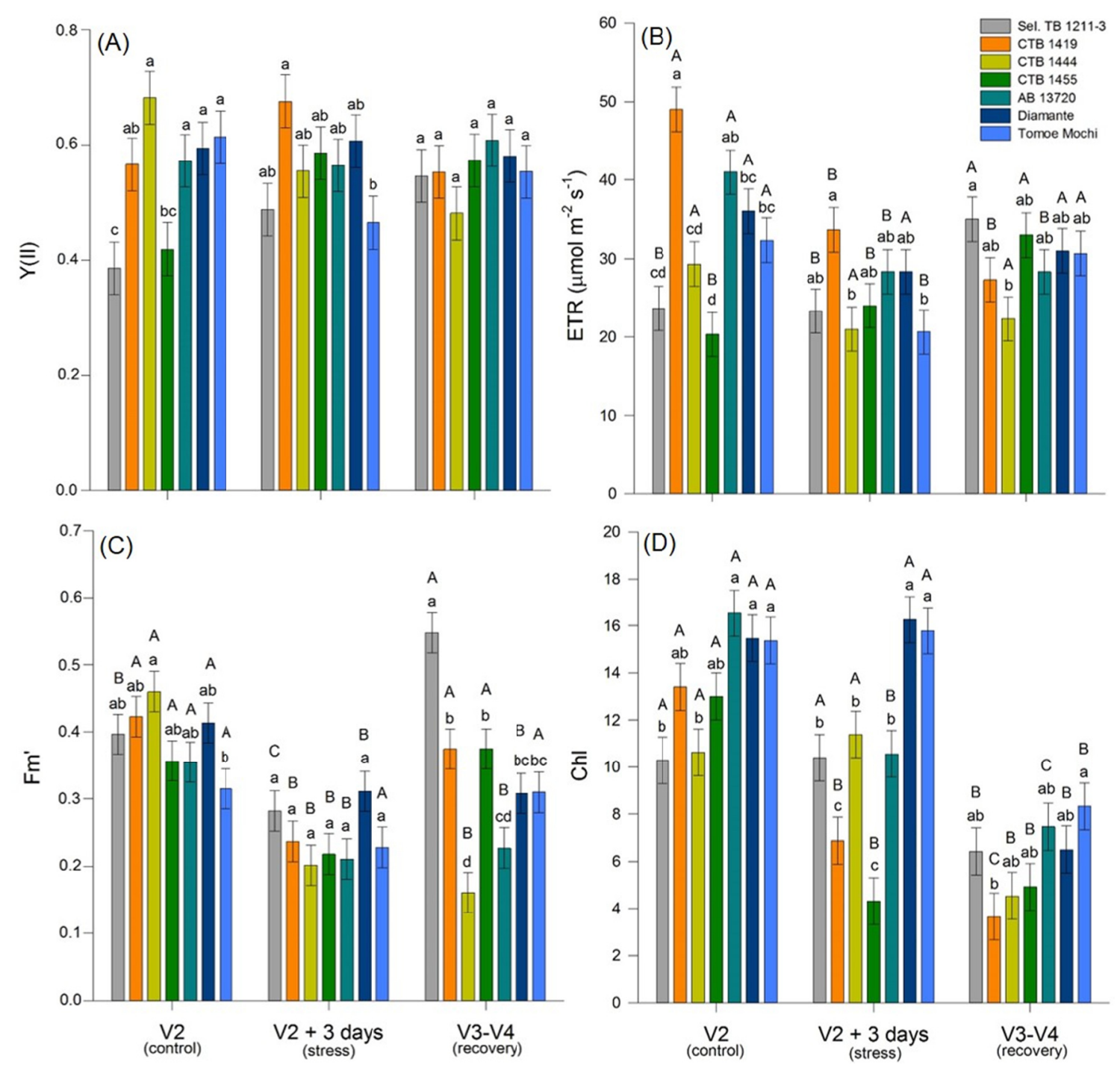

Figure 4. The effects of decreasing temperature on chlorophyll fluorescence parameters of rice leaves along all trial period including after recovery period. Y(II), ETR, Fm' and Chl in the Y-axes refers to effective photochemical quantum yield, electron transfer rate, Fluorescence maximum light acclimated and chlorophyll content, respectively. Values are means $( \pm \mathrm{SD})$ of six plants. These genotypes were chosen based in its performance evidenced by multivariate analyses conducted before

Note. For all genotypes followed by the same lowercase letter on each stage of analysis, they are not significantly different at the $p<0.05$ level by the Student-Newman-Keuls test. For each genotype followed by the same capital letter, they are not significantly different at the $p<0.05$ level by the Student-Newman-Keuls test between stage of analysis.

AB 13720 genotype showed the highest values for root biomass accumulation $(+26 \%)$ when compared to better tolerant check (Tomoe Mochi). In other way, at recovery their shoot biomass accumulation was lower (-48\%) than this tolerant check (Figure 5). 


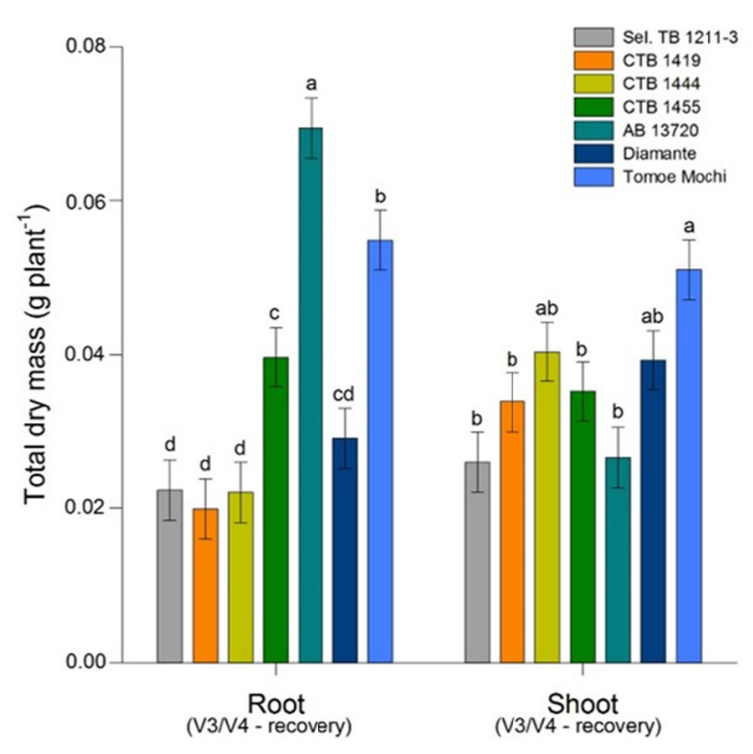

Figure 5. The effects of decreasing temperature on root and shoot biomass accumulation. Values are means $( \pm \mathrm{SD})$ of six plants. These genotypes were selected based in its performance evidenced by multivariate analyses conducted before

Note. For all genotypes followed by the same lowercase letter on each part of plant, they are not significantly different at the $\mathrm{p}<0.05$ level by the Student-Newman-Keuls test.

\section{Discussion}

In fact, rice crop in temperate climates and/or elevated altitudes are continuous exposed to infra-optimum temperatures at least in some development phase during growth season. As an additional factor, the increasingly in extreme weather events registered in last decades can worse this scenario. Nowadays, there are forecasts predicting that the world rice production should increase in about 20 percent until 2035 year (Brar et al., 2017). Thus, the current effects of biotic and abiotic stresses should be mitigated aiming to overcome these constraints that still limit the gain in rice productivity.

In the present study, the performance of rice genotypes under infra-optimum temperatures and its recovery capacity were evaluated considering their physiological responses. Consistent with results reported in previews studies (Hirotsu et al., 2005; Yamori et al., 2011; Fukayama et al., 2015; Moraes de Freitas et al., 2016; Morita et al., 2017), in general infra-optimum temperatures leaded to decreases in chlorophyll content, disrupts in photosystem reaction centers (I and II), changes the anti-oxidative metabolism and consequently slows biomass accumulation rate. In this way, among 42 evaluated genotypes the Sel. TB 1211-3, CTB 1419, CTB 1444, CTB 1455 and $\mathrm{AB} 13720$ progenies showed greater performance for the physiological analyzed variables; showing similar performance as Diamante and Tomoe Mochi which were used as tolerant checks for this study. The chlorophyll content, Y(II) and ETR values shown by these genotypes indicate beyond its better physiological responses still evidenced their greater recovery capacity at the end of stress of stress period.

Stresses by supra and infra-optimum temperatures has been associated to decreases in ratio of reduced acceptors (plastoquinone $-\mathrm{Q}_{\mathrm{A}}$ and $\mathrm{Q}_{\mathrm{B}}$ ), which include $\mathrm{Q}_{\mathrm{A}}$ dynamics transfer to reaction centers as also a reduction in acceptors from $Q_{B}$ to $Q_{A}$. As evidenced by our data, was verified an increase in $F_{0}$ ' whereas a decrease in Fm' what has been also detected by other studies (Mishra et al., 2011; Kalaji et al., 2016). There are reports showing that increases in $\mathrm{F}_{0}$ ' can be attributed to the irreversible dissociation of LHC II from the photosystem II complex beyond of partly reversible inactivation of photosystem II (Yamane et al., 1997). According to this study, the decrease in the fluorescence Fm' can be associated to denaturation of chlorophyll-proteins complex. After the recovery period, there were different responses among evaluated genotypes, with Sel. TB 1211-3 line and CTB 1419 progeny showing better physiological responses (Y(II) and ETR) at the end of stress. Additionally, the chlorophyll content continued to decrease after the recovery period, what is interesting when considering that chlorophyll pigments are related to primary photochemistry and a parameter related to electron transport (Strasser et al., 2004). This evidence tendency could be attributed to time required by plants to reprogram and 
repair its metabolic pathways considering that the analyses were done seven days after the end of the stress period.

Finally, even though great advances in sensors and devices technologies for plant phenotyping in large-scale are now available, there are limitations to associate selected genotypes obtained via image approach to a physiological trait that contribute decisively for those performance; especially considering that the most of available phenotyping platforms can only quantify the morphometrics data, such as leaf and shoot area e plant biomass accumulation. In this way, as demonstrated by our study, not always a fast biomass accumulation can be translated in greater physiological performance. Thus, in breeding program where multiples genotypes need to be characterized routinely, strong efforts should be put in the development and validation of robust physiological and non-invasive approaches to overcome the bottlenecks existent between our capacity associated to underling mechanisms that play the major roles in external and morphometrics phenotypic traits. These advances could allow us to integrate them as useful tolls in a breeding program routine aiming to construct the better plant ideotype for a specific environment.

Summarizing, the chlorophyll fluorescence appear as an useful tool for discriminating multiples genotypes when subjected to infra-optimum temperatures; beyond allow to probe the photosystem II state functioning in a non-invasive form, what is very interesting considering the possibility to return at the same leaf target area to monitor photochemistry changes performance across different stress scales. These selected genotypes (Sel. TB 1211-3 line and the CTB 1419, CTB 1444, CTB 1455 and AB 13720 progenies) showed greater performance for at least of physiological analyzed variables; showing similar performance as shown by tolerant checks for at least one of the physiological evaluated variables. As before described, valorous japonica alleles probably are being introgressed as result of used cross combinations, considering that all selected genotypes are originated from indicaljaponica cross. Therefore, these selected genotypes can be useful as sources for breeding efforts aiming the improvement of rice for cold tolerance at initial stages of plant development.

\section{Acknowledgements}

Financial support was provided by Brazilian Agricultural Research Corporation - EMBRAPA via Macro II Edital.

\section{References}

Baker, N. R. (2008). Chlorophyll fluorescence: A probe of photosynthesis in vivo. Annual Review of Plant Biology, 59(1), 89-113. https://doi.org/10.1146/annurev.arplant.59.032607.092759

Brar, D. S., Singh, K., \& Khush, G. S. (2017). Chapter 6: Frontiers in rice breeding. In S. Mohanty, P. G. Chengappa, Mruthyunjaya, et al. (Eds.), The future rice strategy for India (pp. 137-160). Academic Press, India. https://doi.org/10.1016/B978-0-12-805374-4.00006-3

Brito, G. G., Caixeta, E. T., Gallina, A. P., Zambolim, E. M., Zambolim, L., Diola, V., \& Loureiro, M. E. (2010). Inheritance of coffee leaf rust resistance and identification of AFLP markers linked to the resistance gene. Euphytica, 173(2), 255-264. https://doi.org/10.1007/s10681-010-0119-x

Brito, G. G., Fagundes, P. R. R., Teló, G. M., Abreu, A. G., Júnior, A. M. M., Franco, D. F., ... Petrine, J. A. (2016). Impact of supra-optimal temperatures on physiology and yield in rice field. Journal of Agricultural Science, 8(2), 27-37. https://doi.org/10.5539/jas.v8n2p27

Brito, G. G., Sofiatti, V., Lima, M. M. A., Carvalho, L. P., \& Silva-Filho, J. L. (2011). Physiological traits for drought phenotyping in cotton. Acta Scientiarum Agronomy, 33(1), 117-125. https://doi.org/10.4025/ actasciagron.v33i1.9839

Companhia Nacional de Abastecimento (Conab). (2017). Acompanhamento da safra brasileira de grãos-Décimo segundo levantamento-Safra 2016/2017. Retrieved from http://www.conab.gov.br/ conteudos.php? $\mathrm{a}=1253$

Counce, P. A., Keisling, T. C., \& Mitchell, A. J. (2000). A uniform, objective, and adaptative system for expressing rice development. Crop Science, 40(2), 436-443. https://doi.org/10.2135/cropsci2000.402436x

Diola, V., Brito, G. G., Caixeta, E. T., Maciel-Zambolim, E., Sakiyama, N. S., \& Loureiro, M. E. (2011). High-density genetic mapping for coffee leaf rust resistance. Tree Genetics \& Genomes, 7(6), 1199-1208. https://doi.org/10.1007/s11295-011-0406-2

Diola, V., Brito, G. G., Caixeta, E. T., Pereira, L. F. P., \& Loureiro, M. E. (2013). A new set of differentially expressed signaling genes is early expressed in coffee leaf rust race II incompatible interaction. Functional \& Integrative Genomics, 13(3), 379-389. https://doi.org/10.1007/s10142-013-0330-7 
Fan, S., \& Brzeska, J. (2014). Feeding more people on an increasingly fragile planet: China's food and nutrition security in a national and global context. Journal of Integrative Agriculture, 13(6), 1193-1205. https://doi.org/10.1016/S2095-3119(14)60753-X

Fan, X., Tang, Z., Tan, Y., Zhang, Y., Luo, B., Yang, M., ... Xu, G. (2016). Overexpression of a pH-sensitive nitrate transporter in rice increases crop yields. Proceedings of the National Academy of Sciences, 113(26), 7118-7123. https://doi.org/10.1073/pnas.1525184113

Fukayama, H., Koga, A., Hatanaka, T., \& Misoo, S. (2015). Small subunit of a cold-resistant plant, Timothy, does not significantly alter the catalytic properties of rubisco in transgenic rice. Photosynthesis Research, 124(1), 57-65. https://doi.org/10.1007/s11120-015-0085-1

Godfray, H. C. J., Beddington, J. R., Crute, I. R., Haddad, L., Lawrence, D., Muir, J. F., ... Toulmin, C. (2010). Food security: The challenge of feeding 9 billion people. Science, 327(5967), 812-818. https://doi.org/ 10.1126/science. 1185383

Guimarães, C. M., Stone, L. F., Brito, G. G., \& Heuert, J. (2017). Evaluation of water-stress tolerance of Acala SJ 2 and Auburn 2 cotton cultivars in a phenotyping platform. Revista Ambiente \& Água, 12(4), 629-642. https://doi.org/10.4136/ambi-agua.2105

Hirotsu, N., Makino, A., Yokota, S., \& Mae, T. (2005). The photosynthetic properties of rice leaves treated with low temperature and high irradiance. Plant \& Cell Physiology, 46(8), 1377-83. https://doi.org/10.1093/ pcp/pci149

Jacquemin, J., Bhatia, D., Singh, K., \& Wing, R. A. (2013). The international Oryza map alignment project: Development of a genus-wide comparative genomics platform to help solve the 9 billion-people question. Current Opinion in Plant Biology, 16(2), 147-56. https://doi.org/10.1016/j.pbi.2013.02.014

Kalaji, H. M., Jajoo, A., Oukarroum, A., Brestic, M., Zivcak, M., Samborska, I. A., ... Ladle, R. J. (2016). Chlorophyll $a$ fluorescence as a tool to monitor physiological status of plants under abiotic stress conditions. Acta Physiologiae Plantarum, 38(4), 102. https://doi.org/10.1007/s11738-016-2113-y

Lisei-de-Sa, M. E., Arraes, F. B. M., Brito, G. G., Beneventi, M. A., Lourenço-Tessutti, I. T., Basso, A. M. M., ... Grossi-de-Sa M. F. (2017). AtDREB2A-CA influences root architecture and increases drought tolerance in transgenic cotton. Agricultural Sciences, 8(10), 1195-1225. https.://doi:10.4236/as.2017.810087

Mishra, A., Mishra, K. B., Höermiller, I. I., Heyer, A. G., \& Nedbal, L. (2011). Chlorophyll fluorescence emission as a reporter on cold tolerance in Arabidopsis thaliana accessions. Plant Signaling \& Behavior, 6(2), 301-310. https://doi.org/10.4161/psb.6.2.15278

Moraes de Freitas, G. P., Basu, S., Ramegowda, V., Braga, E. B., \& Pereira, A. (2016). Comparative analysis of gene expression in response to cold stress in diverse rice genotypes. Biochemical and Biophysical Research Communications, 471(1), 253-259. https://doi.org/10.1016/j.bbrc.2016.02.004

Morita, R., Nakagawa, M., Takehisa, H., Hayashi, Y., Ichida, H., Usuda, S., ... Abe, T. (2017). Heavy-ion beam mutagenesis identified an essential gene for chloroplast development under cold stress conditions during both early growth and tillering stages in rice. Bioscience, Biotechnology and Biochemistry, 81(2), 271-282. https://doi.org/10.1080/09168451.2016.1249452

Moura, D. S., Brito, G. G., Campos, Â. D., Moraes, Í. L., Fagundes, P. R. R., \& Deuner, S. (2017a). Phenylalanine ammonia-lyase and source-flow-sink related attributes in rice genotypes subjected to high night temperatures. Journal of Agricultural Science, 9(12), 268-282. https://doi.org/10.5539/jas.v9n12p268

Moura, D. S., Brito, G. G., Campos, Â. D., Moraes, Í. L., Porto, F. G. S., Teixeira, S. B., ... Deuner, S. (2017b). Non-structural carbohydrates accumulation in contrasting rice genotypes subjected to high night temperatures. Journal of Agricultural Science, 9(12), 302-315. https://doi.org/10.5539/jas.v9n12p302

Olivier, J. G. J., Schure, K. M., \& Peters, J. A. H. W. (2017). Trends in global $\mathrm{CO}_{2}$ and total greenhouse gas emissions (Vol. 2983). PABLO Publishers. Netherlands Environmental Assessment Agency, Netherlands.

Shakiba, E., Edwards, J. D., Jodari, F., Duke, S. E., Baldo, A. M., Korniliev, P., ... Eizenga, G. C. (2017). Genetic architecture of cold tolerance in rice (Oryza sativa) determined through high resolution genome-wide analysis. PLoS ONE, 12(3), 1-22. https://doi.org/10.1371/journal.pone.0172133

Strasser, R. J., Tsimilli-Michael, M., \& Srivastava, A. (2004). Analysis of the chlorophyll a fluorescence transient. In G. C. Papageorgiou, \& Govindjee (Eds.), Chlorophyll a fluorescence: A signature of 
photosynthesis (pp. 321-362). Springer Netherlands, Dordrecht. https://doi.org/10.1007/978-1-40203218-9_12

Weber, R. L., Wiebke-Strohm, B., Bredemeier, C., Margis-Pinheiro, M., Brito, G. G., Rechenmacher, C., ... Bodanese-Zanettini, M. H. (2014). Expression of an osmotin-like protein from Solanum nigrum confers drought tolerance in transgenic soybean. BMC Plant Biology, 14, 343. https://doi.org/10.1186/s12870-0140343-y

Yamane, Y., Kashino, Y., Koike, H., \& Satoh, K. (1997). Increases in the fluorescence fo level and reversible inhibition of photosystem ii reaction center by high-temperature treatments in higher plants. Photosynthesis Research, 52(1), 57-64. https://doi.org/10.1023/a:1005884717655

Yamori, W., Sakata, N., Suzuki, Y., Shikanai, T., \& Makino, A. (2011). Cyclic electron flow around photosystem I via chloroplast $\mathrm{NAD}(\mathrm{P}) \mathrm{H}$ dehydrogenase (NDH) complex performs a significant physiological role during photosynthesis and plant growth at low temperature in rice. The Plant Journal: For Cell and Molecular Biology, 68(6), 966-76. https://doi.org/10.1111/j.1365-313X.2011.04747.x

Yoshida, S. (1981). Fundamentals of rice crop science. Los Baños: IRRI

Yuan, Z., Cao, Q., Zhang, K., Ata-Ul-Karim, S. T., Tian, Y., Zhu, Y., ... Liu, X. (2016). Optimal leaf positions for SPAD meter measurement in rice. Frontiers in Plant Science, 7(719). https://doi.org/10.3389/ fpls.2016.00719

Zhao, J., Zhang, S., Dong, J., Yang, T., Mao, X., Liu, Q., ... Liu, B. (2017). A novel functional gene associated with cold tolerance at the seedling stage in rice. Plant Biotechnology Journal, 15(9), 1141-1148. https://doi.org/10.1111/pbi.12704

\section{Copyrights}

Copyright for this article is retained by the author(s), with first publication rights granted to the journal.

This is an open-access article distributed under the terms and conditions of the Creative Commons Attribution license (http://creativecommons.org/licenses/by/4.0/). 